\title{
Participatory Analysis of Crop Production Constraints and Opportunities in Dire Dawa Admnistratration Eastern Ethiopia
}

Kibret Ketema (Corresponding Author)

Fedis Agricultural Research Center P.O. Box, 904 Harar, Ethiopia

Email: kebret2012@gmail.com

\author{
Alemayehu Biri \\ Fedis Agricultural Research Center P.O. Box, 904 Harar, Ethiopia \\ Dagnachew Lule \\ Oromia Agricultural Research Institute Head Quarter, Addis Ababa, Ethiopia
}

\author{
Article History \\ Received: January, 52020 \\ Revised: January 30, 2020 \\ Accepted: February 7,2020 \\ Published: February 9, 2020 \\ Copyright (c) 2020 ARPG \& \\ Author \\ This work is licensed under \\ the Creative Commons \\ Attribution International \\ (9) (1) CC BY: Creative \\ Commons Attribution \\ License 4.0
}

\begin{abstract}
Participatory agricultural production constraint analysis was conducted in AGP-II project supported district; Biyo-Awale district from Dire Dawa Adminisrative Councile (DDAC) of Ethiopia with the objective to assess agricultural production constraints of the target community in the study area. The study was used Participatory Rural Appraisals (PRA) approach to collect and generate the required data and infortation. The study used PRA tools which included reviewing secondary data, focus group discussions, pair-wise ranking, and field observation. Results of PRA study revealed that the main crop production constraints facing the study area are shortage of improved crop varieties for cereal and horticultural crops, pest infestation (weeds, crop disease, and insects), moisture stress due to eratic rainfall distribution and inadequate moisture management practices. The PRA study also revealed that crop production was constraints facing are drought, deforestation, depletion of water resource and declining of soil fertility. The PRA study further indicates shortage of financial capital, and inadequate support in the income source diversification have been identified as major institutiona constraints that are limiting the capacity of the communities to diversify their livelihoods. Hence, there is need for research, development and institutional interventions to alleviate the identified constraints to crop production and socioeconomic in the study area through holistic approach.
\end{abstract}

Keywords: Participatory analysis; Crop production; Constraints; Opportunities; Diredawa.

\section{Introduction}

In Ethiopia, agriculture is main economic pillars of the Ethiopian economy and the overall economic growth of the country is highly dependent on the success of the sector. The sector account for $42 \%$ of the gross domestic product (GDP) of the country and about $85 \%$ of the population gains their livelihood from agricultural production [1]. Crop production sub-sector constitutes a major share in agricultural production and contributes a significant amount to the national domestic product of the country. The crop production accounted for 31.5 and $30.4 \%$ of GDP in 2010/11 and 2011/12 respectively [2]. Increasing crop production is crucial for attaining food security and boosting export earnings of the country.

Crop production constitutes a major share in agricultural production and contributes a significant amount to the national domestic product and it accounted for 31.5\% and 30.4\% of GDP in 2010/11 and 2011/12. This in turn clearly demonstrates the significance of crop production in the drive to accelerate economic growth of the country [3]. As a result, the Ethiopian government has been making significant efforts in transforming the agricultural sector through its Agricultural Growth Program-II (AGP-II) in the country to boost the agricultural sector as the engine of the country overall growth. From eastern part of the country, Dire Dawa Administrative Council is one of the parts of the country addressed by the AGP-II. In the administration, agriculture is continuing as a means of livelihood for rural households of the Administration and which contribute about $53.7 \%$ of the total household income [4]. The Ethiopian government has been making significant efforts in transforming the agricultural sector through agricultural growth program (AGP-II) in the country. In eastern part of Ethiopia, particularly in Dire Dawa Administrative Council (DDAC), agriculture is continuing as a means of livelihood for rural households of the councile.

Crop production such as sorghum, maize, fruits and vegetables are major crops grown the the area. Despite its importance and potential, agricultural production in general and crop production in particularly is facing several constraints hinder its production [5]. Climate change, moisture stress, flood, natural resources degradation, and low level of use of improved technologies are among the major constraints [6]. To reverse this situation, the government has been involved with research and development interventions through AGP-II in the council. To reverse this situation, the government has been involved with research and development interventions through AGP-II in the administration. However, before planning to any agricultural research and development intervention, it imperative to 
design and conduct analysis of agricultural production systems with the aim of assessing crop production syetem, constraints in order to identify potential interventions for enhancing crop production. Accordingly, participatory rural appraisal (PRA) study was conducted to identify and priortrize crop production constraints and opportunities in the target areas. .

A total of two districts namely Biyo-Awale and Wahile are AGP-II supported districts found in the DDAC. Both districts are releatively potential in resource available such as farm land, water for irrigation and domestic use, and for improving production and productivity of crops of the councile. However, before planning to any agricultural research and development activities to be implemented, it imperative to design and conduct an assessment of agricultural production systems to identify production constraints from the grass root. Accordingly, a bottom to up approach of participatory rural appraisal (PRA) tools was used to identify and priortrize the existing crop production constraints in the AGP-II supported districts of the Councile. The PRA study was conducted in the Biyo-Awale district of the Councile. The PRA tools used included, among others, reviewing secondary data, focus group discussions, field observation and Pair-wise ranking. This report highlights the main findings, and implications to AGP-II interventions in the study area.

\section{Methodology}

\subsection{Description of Study Area}

The study was carried out in Dire Dawa Administration Council (DDAC). The Council is located in the eastern part of the Ethiopia. It stretches between $9^{0} 27^{\prime} \mathrm{N}$ and $9^{\circ} 49^{\prime} \mathrm{N}$ latitude and $41^{\circ} 38^{\prime} \mathrm{E}$ and $42^{0} 19^{\prime} \mathrm{E}$ longitude. According to the Atlas of the Ethiopia (ATLAS, 2011).The total area of the administration is 128,802 hectares out of which $98 \%$ is rural area and the remaining $2 \%$ is urban areas and the Administration shares common boundaries with Somali National Regional States in the West, North and East and Oromia National Regional State in the Southern. The council is a chartered city administration that consists of 9 urban and 38 rural kebeles. Agro-ecologically, the administrative is mainly categorized in two agro-ecological zones; warm semi arid (lowland) and dry sub-humid (midland). About $88 \%$ of the land area of the administration is estimated to be warm semi arid (lowland), while the remaining $12 \%$ is sub-humid (midland).

The rainfall pattern of the Administration has a bimodal characteristic. The mean altitude of the administration is 1260 meter above sea level ranging from 960 meter above sea level in the northeast to 2450 meter above sea level in the southwest (EPA, 2010). The average annual rainfall is $618.3 \mathrm{~mm}$. The mean annual temperature is about $24.8^{\circ} \mathrm{C}$. Based on the population projection from CSA (2007), the total population of the Council is estimated to be about 440,000 of which 221, 000 are male and 219, 000 female. The mixed farming is the major economic activity in the rural area of the Administration (96\%). Crop production subsystem is both rain fed and irrigated. The major crops grown are sorghum, maize, onion, tomato, pepper and cabbages, coffee and fruit crops like papaya, banana are also grown in the area. In addition, livestock such as goats, sheep, cattle and camel are reared in the administration.

\subsection{Sampling Procedure}

The survey was conducted in selected Clusters of DDA where the AGP-II program is being implemented. The survey used a participatory rural appraisal (PRA) approach. Prior to going into the survey, a team of experts consisting of different disipline was established. Before starting the survey, the team was discussed with experts from DDA of Agriculture and Natural Resource Offices to identify districts and Kebeles targeted by the AGP-II program to develop sampling design. According to the AGP-II strategic work plan prepared by Agricultural Offices of DDA, two clusters where Biyo Awale and Wahile were selected.

For this survey, purposive sampling technique was used to select representative Clusters, Kebeles and farm households. Different factors were considered in selecting cluster, Kebeles and farm households. Accordingly, Biyo Awale Cluster was selected purposively based on its potential in crop production, agro ecology and available resources such as land, irrigation water. Following similar procedure, three Kebeles namely Adada, Awale and Bishan Bahe were selected for the survey. Moreover, different factors that were supposed affecting the quality of data to be generated were considered in selecting farm households. Accordingly, total number of household heads, total number of population, sex and age of the head of the households were considered during selection of sample farmers. Throughout the PRA a total of 100 farm households and experts were participated during the survey, out of these; about $18 \%$ of the participants were female farmers.

\subsection{Sources and Method of Data Collection}

Review of secondary data: the survey started with review of different published and unpublished documents and reports about the DDA. Secondary data on area description of AGP-II districts were collected from Agriculture Offices. PRA tools such as Focus group discussions (FGDs), Key informant interviews and field observetion were used to collect the primary data from the farm households on crop production and socio-economic constraints.

\subsection{Data Analysis}

The data collected from different sources were checked for consistence and completeness and analyzed using descriptive statistics such as percentage, maens, frequency and ranking to draw and generate useful information. 


\section{Results and Discussion}

\subsection{Description of Study District}

Biyo awale is one of three rural clusters found in the DDAC. The district is located in the south east of the administration. The administration of the district is found in Biyo Awale Kebele; which is located at a distance of 24 $\mathrm{km}$ from the capital city of the administration, Dire Dawa city. The district comprises of 21 rural kebeles, of which 12 Kebeles were selected by office of agriculture for AGP-II intervention. The district is estimated to have a total area of 54,522 ha which accounts to $35 \%$ of the total area of the DDAC. The district has a total of 17,851 household heads of which 2,552 female headed households. According to the 2007 CSA projection as of 2014 the population of the district is about 90,557 of which $52 \%$ are male and $48 \%$ female. The district is mainly categorized in three agroecological areas, of which $76 \%$ of the total area is dry midland, $19 \%$ dry lowland (Table 1).

Table-1. Percentage of area coverage by agro ecology in the study area

\begin{tabular}{l|l|l}
\hline No & Agro-ecologies & Percentage of area coverage \\
\hline 1 & Dry low land (Lowland) & $19 \%$ \\
\hline 2 & Dry mid land (Midland) & $76 \%$ \\
\hline 3 & High land (highland) & $5 \%$ \\
\hline & Total & 100 \\
\hline
\end{tabular}

The rainfall pattern of the district has a bimodal characteristic. The small rainy season is from March to April; while the main rainy season extends from August to mid-September with average annual rainfall of the area is 500 $\mathrm{mm}$ with a range of $900 \mathrm{~mm}$ and $700 \mathrm{~mm}$ average maximum and minimum rainfall, respectively. The mean altitude the district is 2000 masl with a range of 1000 to 3000 masl. Soil type of the area is dominated by sandy soil which has low water holding capacity and very little amount of clay and silt. According to the information received from the Bureau of Agriculture, about $80 \%$ of the soil of the districtis sandy soils. The area is dominated by mountain and hills, shallow and infertile soils are the major characteristics of the area while deep and fertile soils are the major features of the valley, and flat plains of the district.The Biyo Awale district has potentially rich in spring, and surface runoff water resources especially during rainy season. The district is also endowed with groundwater resources abstracted mainly from upper sandstone and limestone aquifers that act as reservoir of the groundwater. According to Dire Dawa Integrated Natural Resource Master Plan Study, 2005, water resource utilization is by far less than the estimated annual recharge in the district. The land use/land cover types in the district can be grouped into three major classes, which are designated as cultivated land, grazing land and bare land. According to the information received from the Bureau of Agriculture, the total area of the district is 54,522 ha, from this, 24,384 ha, 10,732 ha and 19,406 ha are cultivated land, grazing and bare land, respectively.

Geographical location of the study areas

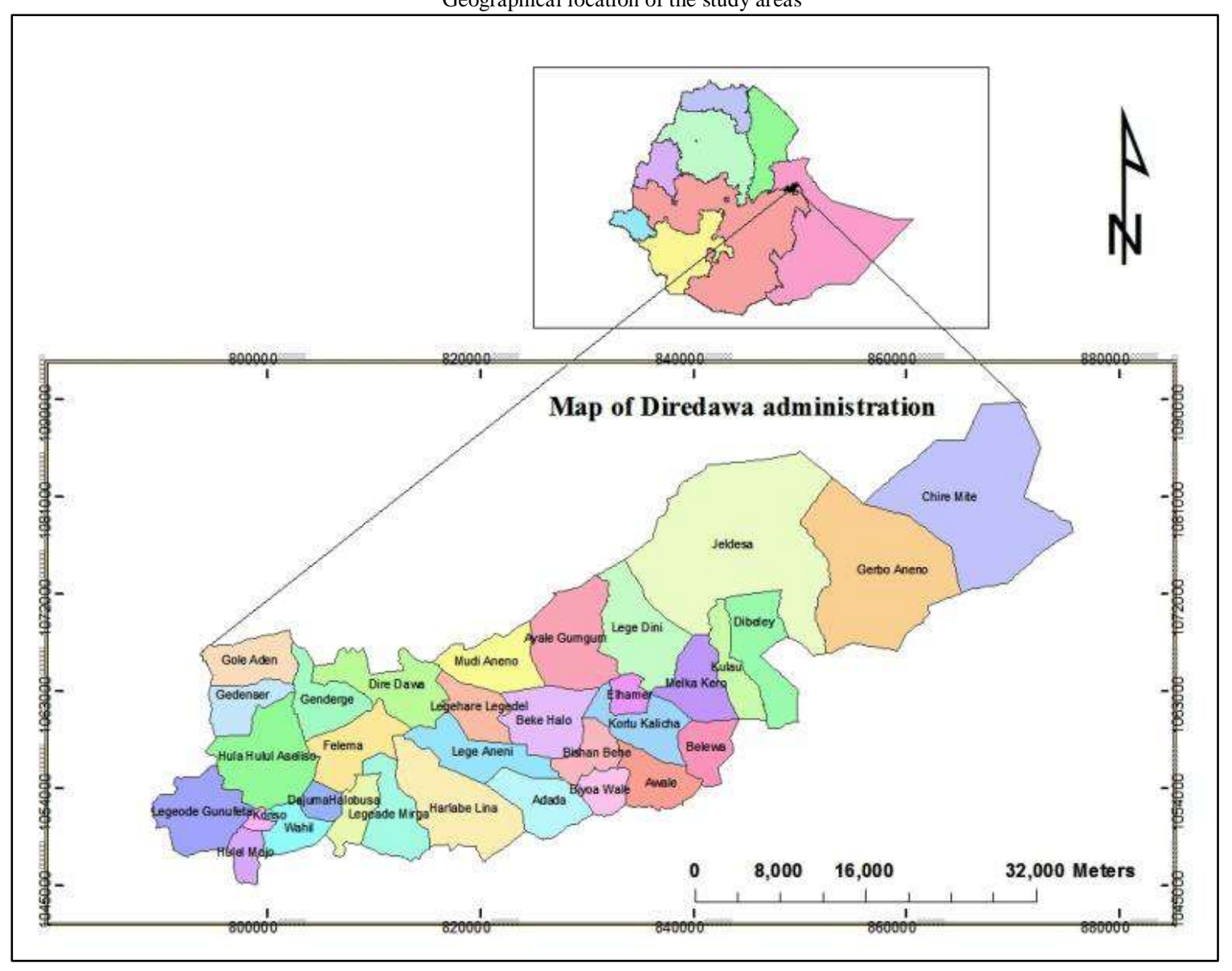




\subsection{Livelihood System and Major Income Sources}

According FGDs, the participant farmers reported that the main sources of income for farm households come from vegetable and fruit products, livestock products and there are also community members engaged in off-farm activities such as buying and selling of vegetable products, live animal and animal products, and petty trade, collection and selling of firewood and charcoal in order to diversify their livelihood and income sources in the study areas. However, the farmers pointed out that there is inadequate support provided to the community in the income source diversification regard by any institutions working with the community. In addition, other factors such as lack of financial support, and market problems are limiting factors the capacity of the communities to diversify their livelihoods.

\subsection{Crop Production}

In the district farmers grow different crops, from cereal crops sorghum and maize are grown commonly. Sorghum is cultivated in the main field and it is the major cereal crop grown under rain fed area, whereas maize is grown under rain fed and irrigation. Besides the cereal crops vegetables and fruit crops such as potato, tomato, onion, papaya, banana, and mandarin are grown as cash crops using irrigation and rainfed. From pulse crops groundnut, haricot bean and sesame are grown. The groundnut is potential cash crops in the area, haricot bean is grown under sowing of sorghum and maize, where sesame is newly introduced crops on area and some farmers produced it on a limited area of fields. The relative importance of major crops grown in the district was presented in Table 2).

The result of FGDs and secondary data shows that from cereal crops, sorghum is the most important crops grown as shown with a rank of first followed by maize in all Kebeles, while from pulse/oil crops groundnut is the most important crops grown as shown with a rank of first followed by haricot bean in all Kebeles. Similarly, from vegetable and fruit crops, tomato and papaya is the most important crops grown as shown with a rank of first in most of Kebeles. Availability of ground water, soil and land management intervention, availability of main cities such as Harar and Dire Dewa, and proximity to Djibouti and Somali are potential opportunities for improving crop production in the study area.

Table-2. Crops produced and their relative importance in the Biyo Awale district

\begin{tabular}{l|l|l|l}
\hline Commodity crops & Dry lowland Kebeles & \multicolumn{2}{|l}{ Dry midland Kebeles } \\
\hline Cereal crops & Adada & Bishan Bahe & Awale \\
\hline Sorghum & 1 & 1 & 1 \\
\hline Maize & 2 & 2 & 2 \\
\hline Finger millet & 3 & - & - \\
\hline Pulse/oil crops & & & \\
\hline Haricot beans & 2 & 2 & 2 \\
\hline Groundnuts & 1 & 1 & 1 \\
\hline Sesame & - & 3 & - \\
\hline Vegetables & & & \\
\hline Tomato & 1 & 1 & 2 \\
\hline Potato & 2 & 2 & 1 \\
\hline onion & 3 & 4 & 3 \\
\hline Chilli pepper & - & 3 & 4 \\
\hline Cabbage & - & 5 & - \\
\hline Fruit & & & \\
\hline Papaya & 1 & 1 & 2 \\
\hline Banana & 3 & 2 & - \\
\hline Mango & 2 & 3 & 1 \\
\hline Mandarin & - & 4 & - \\
\hline Coffee & 4 & 5 & 3 \\
\hline Source: FGDs in the target area, 2017 ranking indicated that the highest area of production &
\end{tabular}

\subsection{Cropping Systems and Pattern}

The district is characterized by diverse and intensive cropping system where most farmers usually grow two or more crops on the same field per year. Figure 1 shows that the most dominating cropping system was mono cropping, which is about $53 \%$ of farmers practiced mono cropping followed by intercropping (21\%) and double cropping $(15 \%)$. Farmers followed mono-cropping practice dominantly by growing one or two crops (sorghum, maize, or groundnut) on the same field per year without practicing crop rotation. During FGDs the farmers mentioned that if the farmers allocate a plot of land for sorghum or groundnut, then they grow sorghum or groundnut year per year. The farmers also practice double cropping in areas where irrigation access is there, by growing tomato at dry season and after harvest of tomato, maize is planted. However, these cropping system practiced by farmers without considering crop combinations, planting times, spacing and planting patterns using their indigenous knowledge. 


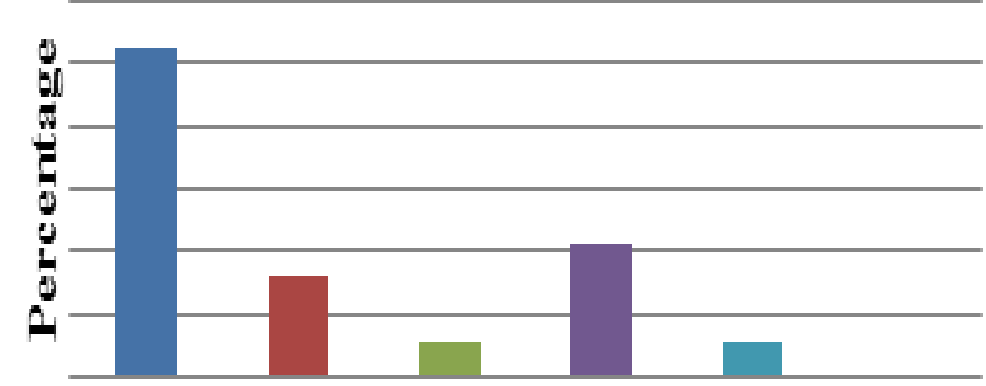

- Mono-...

\section{Cropping system}

The cultivated area of land under all crops is high for the last five production year 2010/11 to 2014/15 (Fig.2). The size of cultivated area under all crops is shows an increasing trend with decreasing rate from 2011 to 2014 and decreasing after 2014 in both areas. This implies that the cultivated land scarcity may face the area. The average cropland holding is also less than 0.5 hectare in the area.

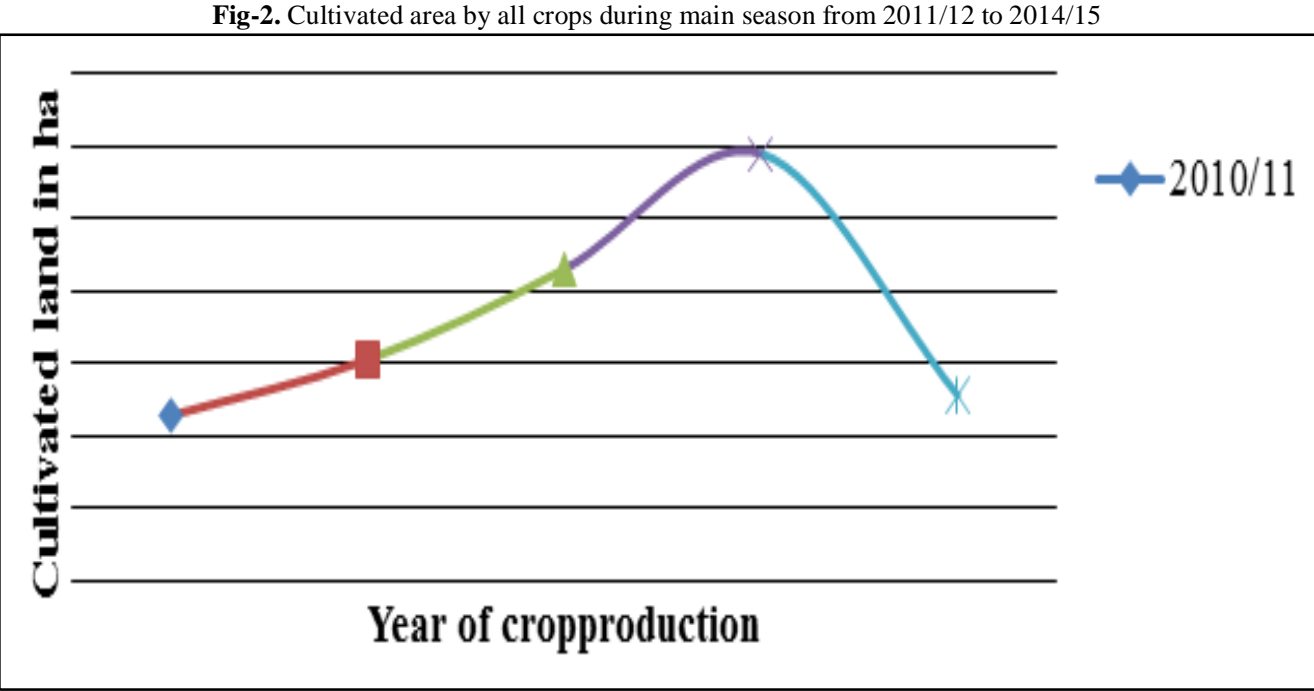

The cultivated area of irrigated land under all crops is shows a tremendous incremental trend in both modern and traditional irrigated land for the last five year of production (2010/11 to 2014/15). However, the irrigated area under modern irrigation is shows smooth incremental trends as compared to area irrigated land under traditional irrigated area the in area. Figure 3 also shows that total irrigated area under modern and traditional irrigation increases from 1469 hectares in 2010/11) to more than a double after five years which about 3205 hectares.

Fig-3. Cultivated area under irrigation

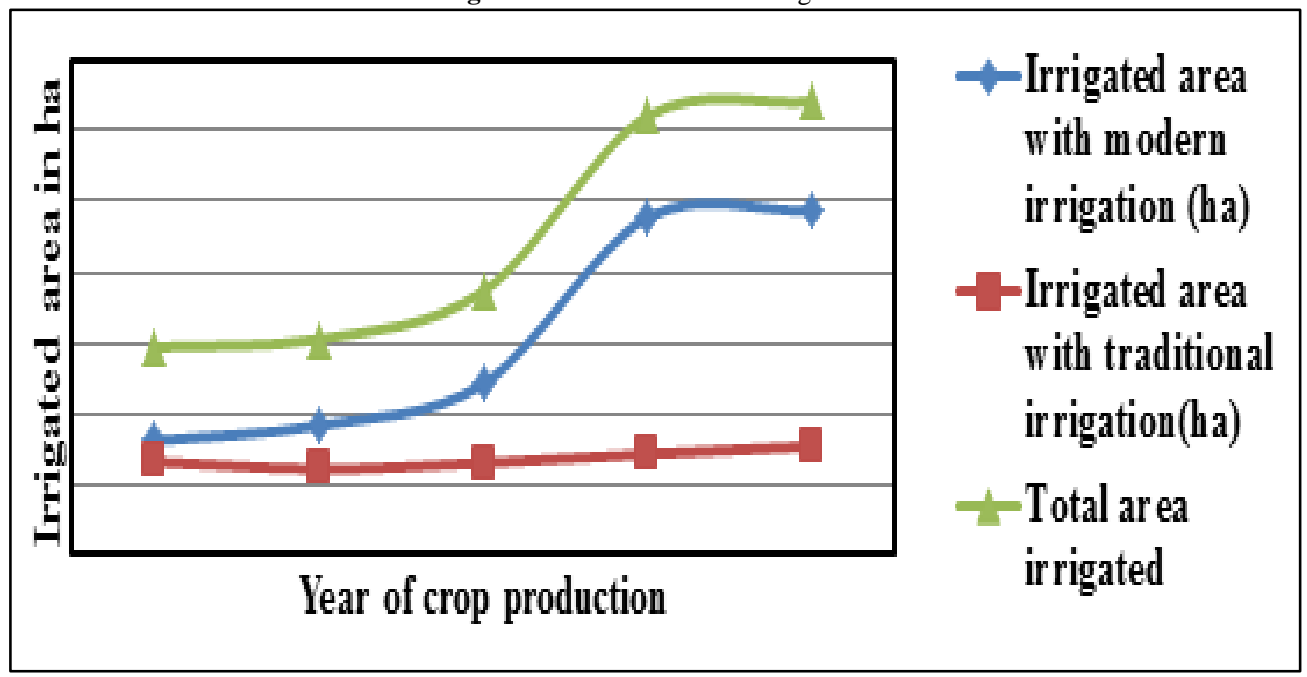




\subsection{Trend of Major Crop Production and Productivity}

The production amount of sorghum, maize and others crops produced in the district shows an increasing trend with some fluctuation of production for the last five years 2010/11 to 2014/15(Fig.4). Fig.4 shows that sorghum has a lion share from cereal production in the area. The trend of vegetable and fruit crops production in the area was increasing at increasing rate for the last five years. This implies that the cultivated area of irrigated land under vegetable and fruit crops was increased in the area.

Fig-4. Amount of crops production during main season from 2010/11 tp 2014/15

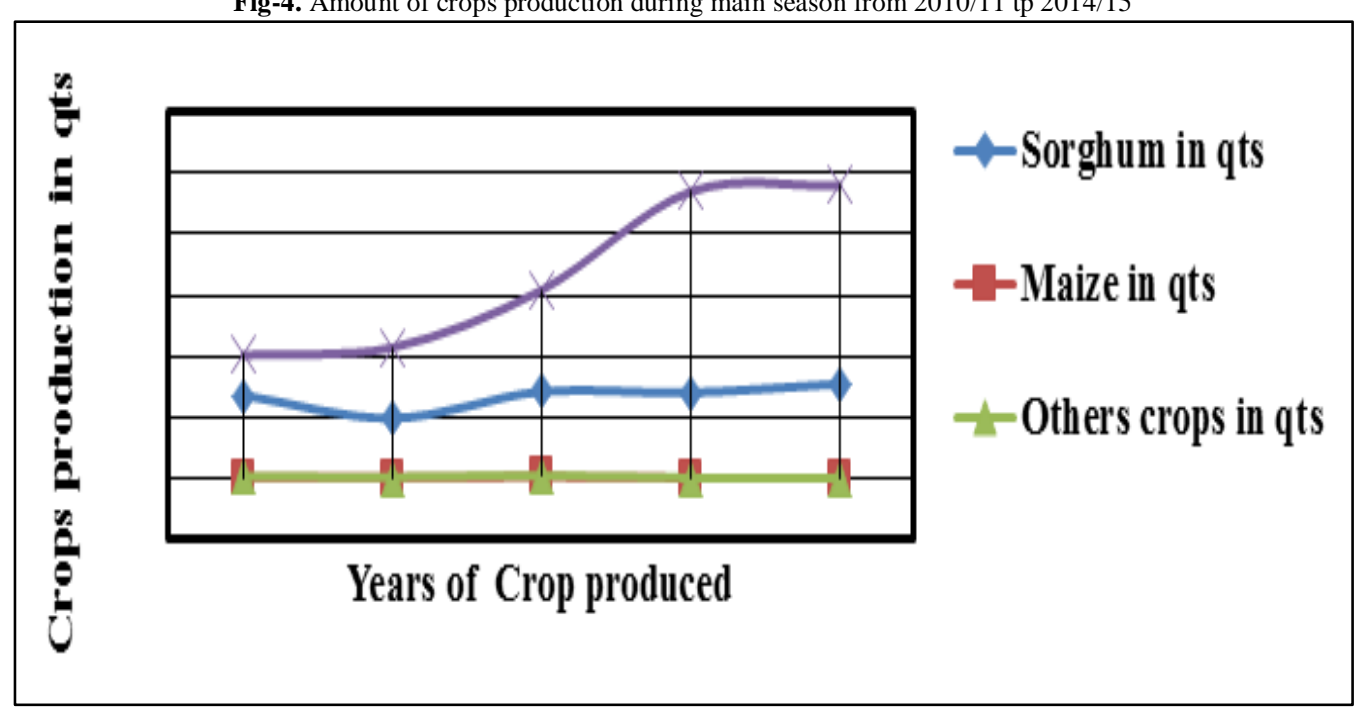

As shown in table 3 the productivitry of sorghum and maize are 14qt/ha, and 15qt/ha respectively. The reason for this low crop productivity might be generally associated with inadequate use of inputs such as improved seeds, moisture, pressure of pests and diseases and inadequate management practices.

Table-3. Crop yield of major crops in the area (qt/ha) in the study areas

\begin{tabular}{l|l}
\hline Commodity crops & Yield $(\mathbf{q t} / \mathbf{h a})$ \\
\hline Cereal crops & \\
\hline Sorghum & $14-16$ \\
\hline Maize & 15 \\
\hline Pulse/oil crops & \\
\hline Haricot beans & 13 \\
\hline Groundnuts & 25 \\
\hline Sesame & 8 \\
\hline Vegetables and fruits & \\
\hline Tomato & 155 \\
\hline Potato & 192 \\
\hline Sweet potato & 200 \\
\hline Papaya & 200 \\
\hline
\end{tabular}

\subsection{Crop Management}

\subsubsection{Soil Fertility Improvement by Crop Types}

Soil fertility management practiced in the study is presented in Table 4. The farmers use combination of farmyard manure with inorganic fertilizers on sorghum, maize, tomato, potato and onion in the area. Compost making and using is not common practices in the study area, but there are few farmers who are using it only on vegetables, maize and khat, by decomposing manure and weeds in pits. During group discussions farmers noted that application of fertilizers at recommended rate is highly contributed to the crop yield increment, however, high cost of fertilizers and moisture stress a limiting factor to use fertilizers.

Table-4. Soil fertility management for major crops in the study area, 2016

\begin{tabular}{|c|c|c|c|c|}
\hline Crop types & $\begin{array}{l}\text { Fertilizer } \\
\text { management }\end{array}$ & $\begin{array}{l}\text { Amount of fertilizer } \\
\text { application/ha }\end{array}$ & $\begin{array}{l}\text { Method of fertilizer } \\
\text { application }\end{array}$ & Time of application \\
\hline Sorghum & $\begin{array}{l}\text { Manure } \\
+ \text { DAP +Urea }\end{array}$ & $\begin{array}{l}\text { DAP }=50-80 \mathrm{~kg} / \mathrm{ha} \\
\text { Urea }=40-50 \mathrm{~kg} / \mathrm{ha} \\
\text { Manure }=10-12 \mathrm{qt} / \mathrm{ha}\end{array}$ & $\begin{array}{l}\text { DAP } \\
\text { broadcasting/mixing } \\
\text { with seed and drilling } \\
\text { Urea = side dressing at } \\
\text { knee stage of the } \\
\text { plant/at } 6 \text { leaf stage } \\
\text { Manure=broadcast }\end{array}$ & $\begin{array}{l}\text { DAP = at planting } \\
\text { Urea = at cultivation } \\
\text { Manure = before } \\
\text { planting }\end{array}$ \\
\hline
\end{tabular}


Journal of Agriculture and Crops

\begin{tabular}{|c|c|c|c|c|}
\hline Maize & $\begin{array}{l}\text { Manure } \\
+ \text { DAP +Urea }\end{array}$ & $\begin{array}{l}\text { DAP }=50-80 \mathrm{~kg} / \mathrm{ha} \\
\text { Urea }=40-50 \mathrm{~kg} / \mathrm{ha} \\
\text { Manure }=1012 \mathrm{qt} / \mathrm{ha}\end{array}$ & $\begin{array}{l}\text { DAP } \\
\text { broadcasting/mixing } \\
\text { with seed and drilling } \\
\text { Urea = side dressing at } \\
\text { knee stage of the plant/ } \\
\text { at } 6 \text { leaf stage } \\
\text { Manure=broadcast }\end{array}$ & $\begin{array}{l}\text { DAP = at planting } \\
\text { Urea = at cultivation } \\
\text { Manure = before } \\
\text { planting }\end{array}$ \\
\hline Groundnut & Manure & Manure 8-10qt/ha & Manure=broadcast & Before planting \\
\hline Sesame & Manure & Manure 8-10qt/ha & Manure=broadcast & Before planting \\
\hline Tomato & $\begin{array}{l}\text { Manure } \\
+ \text { DAP +Urea }\end{array}$ & $\begin{array}{l}\text { DAP }=100-120 \mathrm{~kg} / \mathrm{ha} \\
\text { Urea }=80-100 \mathrm{~kg} / \mathrm{ha}\end{array}$ & $\begin{array}{l}\text { DAP }=\text { broadcasting } \\
\text { Urea }=\text { side dressing at } \\
\text { transplanting and }\end{array}$ & $\begin{array}{l}\text { DAP }=\text { at } \\
\text { planting/transplanting } \\
\text { Urea = at flowering } \\
\text { stage }\end{array}$ \\
\hline Potato & $\begin{array}{l}\text { Manure } \\
+ \text { DAP +Urea }\end{array}$ & $\begin{array}{l}\text { DAP }=80-100 \mathrm{~kg} / \mathrm{ha} \\
\text { Urea }=100-120 \mathrm{~kg} / \text { ha }\end{array}$ & $\begin{array}{l}\text { DAP }=\text { band } / \text { drilling } \\
\text { Urea }=\text { side dressing }\end{array}$ & $\begin{array}{l}\text { DAP }=\text { at } \\
\text { planting/transplanting } \\
\text { Urea = at first and } \\
\text { second } \\
\text { cultivation }\end{array}$ \\
\hline Onion & $\begin{array}{l}\text { Manure } \\
+ \text { DAP +Urea }\end{array}$ & $\begin{array}{l}\text { DAP }=60-80 \mathrm{~kg} / \mathrm{ha} \\
\text { Urea }=50 \mathrm{~kg} / \mathrm{ha}\end{array}$ & $\begin{array}{l}\text { DAP }=\text { band } / \text { drilling } \\
\text { Urea }=\text { side dressing }\end{array}$ & $\begin{array}{l}\text { DAP = before } \\
\text { seedling } \\
\text { Urea = at first inter } \\
\text { cultivation practice }\end{array}$ \\
\hline
\end{tabular}

The PRA study identified major soil erosion types such as Gulley erosion, Sheet erosion and Rill erosion and wind erosion in the area. These erosions are affecting the land resource by eroding fertile soil, and reducing farm and grazing land by forming gullies. Soil bunds, stone bunds, terraces, check-dams, cut off drains and watershed management are the most common bio-physical measures used by farmers for soil and water conservation in the area. They also mentioned that watershed management through area closures and aforestation of degraded areas are practicing to control runoff. Moreover, grass strips and planting of multipurpose trees along the soil bunds, and contour to control soil erosion are also practicing as a biological measure in the area However, biological measures for soil and water conservation practices in most areas is not significant as compared to physical.

\subsubsection{Trend of Inorganic Fertilizer Supply}

Fig.5 shows that DAP and Urea supplied by office of agriculture for the last five consecutive years. From the figure the supply trends of both DAP and Urea is fluctuating, this may due to rainfall distribution in the area.

Fig-5. Quantity of fertilizers supplied by agricultural office in the past five years in qt

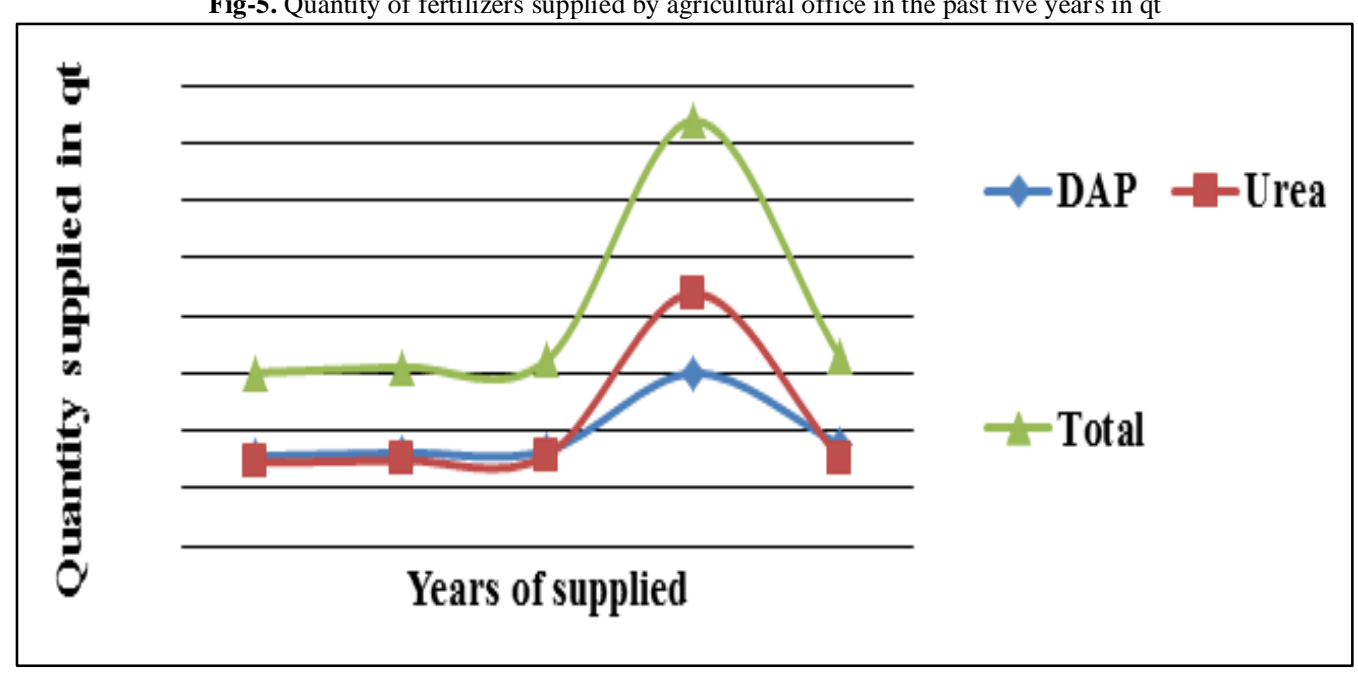

\subsubsection{Type of Seeds used and Source}

The farmers accessed seeds from different sources in the study area. For sorghum, maize, haricot bean and groundnut, own saved, farmers and village market are common source for seeds of these crops. The mproved seeds of sorghum, maize, haricot bean, tomato, papaya and mango, farmers obtained from Office of agriculture, NGOs (emergency), and local market (for tomato and onion). During group discussion, the armers asserts that there is limited access to only few improved varieties of maize such as melkasa-2 and katuman, improved seeds of tomato such as Shante, Konchor and Roma-VF, onion (Adama red) and mango (grafted mango) through which are supplied through offices of agriculture, and NGOs for emergency. The farmers noted that there are no improved varieties for most crops although there are limited improved varieties provided to the area. 


\subsubsection{Agronomic Practices}

In study area, for maize and sorghum, land preparation is usually performed using oxen-plough, and hand tools using human labour for the purpose of moisture conservation and weed control. Similarly, for vegetable and fruit crops land ploughing is performed using oxen ploughs for primary tillage, and hand tools such as Hararghe Akafa and Dangora using human labour. Moreover, during group discussion different farmers' crop management practices identified such as tillage frequency, planting methods, and cropping practices are presented in table 5.

Table-5. Major agronomic practices used by farmers in the study areas

\begin{tabular}{|c|c|c|c|c|c|c|}
\hline Crop types & $\begin{array}{l}\text { Method of } \\
\text { plough }\end{array}$ & $\begin{array}{l}\text { Tillage } \\
\text { frequency }\end{array}$ & $\begin{array}{l}\text { Planting } \\
\text { methods }\end{array}$ & $\begin{array}{l}\text { Cropping } \\
\text { practice }\end{array}$ & $\begin{array}{l}\text { Harvesting } \\
\text { technique }\end{array}$ & $\begin{array}{l}\text { Threshing } \\
\text { methods }\end{array}$ \\
\hline Sorghum & $\begin{array}{l}\text { Ploughed } \\
\text { with } \\
\text { ox } \\
\text { ploughs/hand } \\
\text { hoe }\end{array}$ & $\begin{array}{l}\text { One to } \\
\text { two }\end{array}$ & Broadcasting & Mono cropping & $\begin{array}{l}\text { Manually } \\
\text { by sickle }\end{array}$ & $\begin{array}{ll}\text { By } & \text { hand } \\
\text { biting } & \text { using } \\
\text { stick } & \end{array}$ \\
\hline Maize & $\begin{array}{l}\text { Ploughed } \\
\text { with } \\
\text { ox ploughs/ } \\
\text { hand hoe }\end{array}$ & $\begin{array}{l}\text { One to } \\
\text { two }\end{array}$ & $\begin{array}{l}\text { Row } \\
\text { planting } \\
\text { Broadcast }\end{array}$ & $\begin{array}{l}\text { Mono cropping } \\
\text { for rainfed } \\
\text { fields, } \\
\text { Rotation for } \\
\text { irrigated }\end{array}$ & $\begin{array}{l}\text { Manually } \\
\text { by sickle }\end{array}$ & $\begin{array}{l}\text { By hand } \\
\text { biting using } \\
\text { stick/hand } \\
\text { pilling }\end{array}$ \\
\hline Groundnuts & $\begin{array}{l}\text { Ploughed } \\
\text { with ox } \\
\text { ploughs/ } \\
\text { hand hoe }\end{array}$ & $\begin{array}{l}\text { One to } \\
\text { two }\end{array}$ & $\begin{array}{l}\text {-Row } \\
\text { planting is } \\
\text { common }\end{array}$ & $\begin{array}{l}\text { Sole cropping } \\
\text { is common } \\
\text { Intercropped } \\
\text { mixed with } \\
\text { sorghum/maize }\end{array}$ & $\begin{array}{l}\text { Manually } \\
\text { by hand } \\
\text { hoe }\end{array}$ & $\begin{array}{l}\text { Striping by } \\
\text { hand and } \\
\text { supplied to } \\
\text { the market } \\
\text { without } \\
\text { shelling }\end{array}$ \\
\hline Tomato & $\begin{array}{l}\text { Ploughing } \\
\text { withox } \\
\text { ploughs/hand } \\
\text { hoe }\end{array}$ & 3 times & $\begin{array}{l}\text { Row } \\
\text { planting }\end{array}$ & Sole cropping & $\begin{array}{l}\text { Manually } \\
\text { by hand } \\
\text { pickin }\end{array}$ & - \\
\hline Potato & $\begin{array}{l}\text { Land is } \\
\text { plough } \\
\text { with ox } \\
\text { ploughs/hand } \\
\text { hoe }\end{array}$ & 3 times & $\begin{array}{l}\text { Row } \\
\text { planting }\end{array}$ & Sole cropping & $\begin{array}{l}\text { Manually } \\
\text { by hand } \\
\text { hoe }\end{array}$ & - \\
\hline Onion & $\begin{array}{l}\text { Ploughed } \\
\text { with } \\
\text { ox } \\
\text { ploughs/hand } \\
\text { hoe }\end{array}$ & 3 times & $\begin{array}{l}\text { Row } \\
\text { planting }\end{array}$ & Sole cropping & $\begin{array}{l}\text { Manually } \\
\text { by hand } \\
\text { pulling }\end{array}$ & - \\
\hline $\begin{array}{l}\text { Chili } \\
\text { Pepper }\end{array}$ & $\begin{array}{l}\text { Land is } \\
\text { ploughed } \\
\text { withox } \\
\text { ploughs/ } \\
\text { hand hoe }\end{array}$ & 3 times & $\begin{array}{l}\text { Row } \\
\text { planting }\end{array}$ & Sole cropping & $\begin{array}{l}\text { Manually } \\
\text { by hand } \\
\text { picking }\end{array}$ & - \\
\hline Cabbage & Hand hoe & 3 times & $\begin{array}{l}\text { Row } \\
\text { planting }\end{array}$ & Sole cropping & $\begin{array}{l}\text { Manually } \\
\text { by hand } \\
\text { picking }\end{array}$ & - \\
\hline
\end{tabular}

\subsubsection{Pest Management Practice}

The major weeds such as Striga, Parthenium, Amaranthus hybrid, Cocklebur and Spotted spurge (Marare) on sorghum and maize, and Orobanche on tomato are among weeds identified by PRA farmers. The farmers also noted that these weeds are not manageable by farmers practice in the study areas. The major disease such as Leaf spot, Leaf blight on sorghum and maize, Powdery mildew, Down mildew, blight on tomato and, blight, on potato and onion, and Anthracnose on mango are among the serious disease reducing crop yields in the area. Insects like stalk borers on maize and sorghum, leaf minor (Tuta absuluta) and aphids on vegetable and thrips, fruit fly on mango were the major insect pests reported by farmers. Farmers used cultural practices like smoking, and removing the affected plant/branches. In addition, farmers used pesticides such as DDT, Marshal, Malathion, and Mankozebfor vegetable crops. 
Journal of Agriculture and Crops

Table-6. Major types of pests and management practices used in study area

\begin{tabular}{|c|c|c|c|c|c|c|}
\hline Major Pest & Sorghum and maize & Sesame & Tomato & Potato & Onion & Mango \\
\hline Weed & $\begin{array}{l}\text { Striga hermonthica, } \\
\text { Striga } \\
\text { asiatica,Parthenium } \\
\text { hysterophorus, } \\
\text { Amaranthus hybrid, } \\
\text { Couch grass, } \\
\text { Cocklebur, } \\
\text { Common } \\
\text { nettle(Anamale) } \\
\text { Oxalis (wanjalii), } \\
\text { Cyprus Spotted spurge } \\
\text { (Marare),Argimon } \\
\text { Mexicana (Arama qore) }\end{array}$ & $\begin{array}{l}\text { Cockleb } \\
\text { ur, } \\
\text { Spotted } \\
\text { spurge } \\
\text { (Marare) } \\
\text {, Spotted } \\
\text { spurge } \\
\text { (Marare) }\end{array}$ & $\begin{array}{l}\text { Orobancha } \\
\text { (Tomabasho) }\end{array}$ & - & - & - \\
\hline $\begin{array}{l}\text { Frequency of } \\
\text { weeding }\end{array}$ & $\begin{array}{l}\text { Three to four times } \\
\text { (hand weeding and } \\
\text { cultivation using hand } \\
\text { hoe for weeding) }\end{array}$ & $\begin{array}{l}\text { Two to } \\
\text { three } \\
\text { times } \\
\text { (cultivati } \\
\text { on }\end{array}$ & $\begin{array}{l}\text { Two to three } \\
\text { times } \\
\text { (cultivation } \\
\text { using hand hoe) }\end{array}$ & - & - & - \\
\hline Insect & $\begin{array}{l}\text { Stalk borer, } \\
\text { Aphids/Macur } \\
\text { (sorghum), African ball } \\
\text { worm (Sorghum), Cut } \\
\text { worm, White fly, } \\
\text { Butterfly, Termite, } \\
\text { Shoot borer, Fruit fly, } \\
\text { Grubs(Qumbursii) }\end{array}$ & $\begin{array}{l}\text { Army } \\
\text { worm } \\
\text { (Geri) }\end{array}$ & $\begin{array}{lr}\text { Spider } & \text { mite, } \\
\text { Cut } & \text { worm, } \\
\text { Fruit } & \text { fly, } \\
\text { Aphid, } & \text { white } \\
\text { flies } & \end{array}$ & $\begin{array}{l}\text { Spider mite, } \\
\text { Fruit fly, } \\
\text { Aphid, white } \\
\text { flies, Moth }\end{array}$ & $\begin{array}{l}\text { Cut } \\
\text { worm, } \\
\text { Thrips, } \\
\text { Mites } \\
\text { and } \\
\text { Worm }\end{array}$ & $\begin{array}{l}\text { Fruit fly, } \\
\text { termite } \\
\text { Aphid, } \\
\text { Thrips } \\
\text { Midge }\end{array}$ \\
\hline Management & $\begin{array}{l}\text { Farm site cleaning, 2-3 } \\
\text { times ploughining, } \\
\text { cut/uprooting and } \\
\text { remove the affected } \\
\text { plant, and } \\
\text { pesticides (DDT, } \\
\text { Marshal, Malathion- } \\
\text { spraying } 2 \text { to } 3 \text { times) }\end{array}$ & $\begin{array}{l}\text { Late } \\
\text { planting, } \\
\text { sprayed } \\
\text { chemical } \\
\text { s(Malath } \\
\text { ion) }\end{array}$ & $\begin{array}{l}\text { Farm site } \\
\text { cleaning, } \\
\text { manuring, } \\
\text { Spraying of } \\
\text { chemeical } \\
\text { (Mankozyeb : } \\
\text { 2-3 times in a } \\
\text { month) }\end{array}$ & $\begin{array}{l}\text { Farm site } \\
\text { cleaning, } \\
\text { manuring, } \\
\text { Spraying } \\
\text { chemical ( of } \\
\text { Mankozyeb: } \\
\text { 2-3 times in a } \\
\text { month) }\end{array}$ & 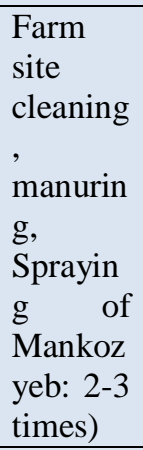 & $\begin{array}{l}\text { Site } \\
\text { cleaning } \\
\text { and } \\
\text { removing } \\
\text { affected } \\
\text { part of the } \\
\text { plants }\end{array}$ \\
\hline Disease & $\begin{array}{lr}\text { Leaf spot, Root rot, } \\
\text { Root knot, Leaf blight, } \\
\text { Head } & \text { smut(on } \\
\text { sorghum) } & \end{array}$ & - & 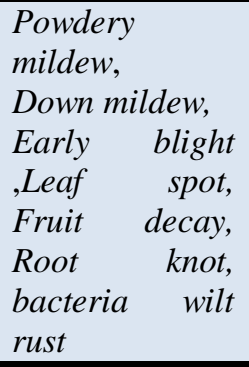 & $\begin{array}{l}\text { Later blight, } \\
\text { Fungal rot, } \\
\text { Leaf spot, } \\
\text { Root knot }\end{array}$ & $\begin{array}{l}\text { Late } \\
\text { blight, } \\
\text { Fungal } \\
\text { rot, } \\
\text { Leaf } \\
\text { spot, } \\
\text { Root } \\
\text { knot }\end{array}$ & $\begin{array}{l}\text { Fruit } \\
\text { decay, root } \\
\text { knot, } \\
\text { Dawny } \\
\text { mildew } \\
\text { Die back } \\
\text { powdermil } \\
\text { dew,Anthr } \\
\text { acnose } \\
\end{array}$ \\
\hline
\end{tabular}

\subsection{Market Services}

The PRA result indicated that involvement of brokers and limited marketing infrastructure development such as market place, information development for crop and livestock products are makes markets are poorly developed in the study area. The farmers are engaged in production of different types of vegetables fruit and animals are produced predominantly for market purpose. Products were taken to the nearby towns by producers in most cases. However, price setting by brokers is among their major marketing problem as large part of the price margins are unfairly taken away by the middlemen.

\subsection{Gender Roles in Crop Production}

The PRA study indicates that the males play a dominant role in cereal crop production activities such as land cleaning, land preparation, inputs preparation, transporting manure to farm fields, planting, cultivation fertilizers application, pest and disease management crop residue collection, harvesting, threshing and transportation of grains to storage while females serving male in food, coffee, tea, and harvesting and marketing of crop products were commonly performed by female in the study area. On the other hand, both females and males are equally involved on decision making on type of crops grown, selling and buying of crop products in the study areas. 


\subsection{Crop Production Constraints}

The livelihood activities of farmers are constraining by various constraintsbsuch as such farm land shortage, most of the land is degraded due to soil erosion, poor soil fertility drought, limited capacity, and lack of access to inputs and improved seeds in the area. However, farmers perceived these constraints and made an effort to feed his/her families through practicing growing various crops such as cereal crops, pulse, vegetable and fruit trees on a plot of land, and constructing soil bunds, and small indigenous ridges on their farm fields to conserve moisture, and use of organic manure to maintain soil fertility. In addition, some farmers also intentionally grow fruit and some multipurpose trees on farm lands in the area.

The major constraining crop productions as explained by farmers are shortage of improved seed varieties for most crops in the study area. The shortage of improved seed varieties was ranked first as a constraining productivity of crops in the study area (Table 7). The result of PRA study also indicates that the moisture stress due to erratic rainfall was the second and third factor which limiting crop production in Adada and Awale, and Bishan Bahe Kebele, respectively. Weed infestation were ranked by farmers, third in Adada, and Awale Kebeles and fourth in Bishan Bahe Kebele as a major factor limiting crop production in the area. Similarly, insects and diseases outbreak were ranked by farmers, third in Adada, and Awale Kebeles, and second in Bishan Bahe Kebele as a constrain for crop prodction. Moreover, harvesting, threshing, and storage were identified as post harvest problem during the PRA study. The result of PRA study further indicates that the access to free market for crop products particularly for vegetables and fruit products was the first most important constraint in the study area. The PRA report also noted high cost of inputs, lack of access to and use of market information, and lack of organized marketing system were identified as main marketing constraints in the study area.

Table-7. Pair-wise ranking of constraints related crop production in the study area

\begin{tabular}{l|l|l|l}
\hline Constraints & \multicolumn{2}{l}{ Name of Kbeles } \\
\hline Production & Adada & Awale & Bishan Behe \\
\hline Shortage of improved varieties & $1^{\text {st }}(4)$ & $1^{\text {st }}(4)$ & $1^{\text {st }}(4)$ \\
\hline Crop insect and disease & $3^{\text {th }}(2)$ & $3^{\text {th }}(2)$ & $2^{\text {nd }}(3)$ \\
\hline Weed infestation & $3^{\text {th }}(2)$ & $3^{\text {th }}(2)$ & $4^{\text {nd }}(1)$ \\
\hline Moisture stress due to erratic rainfall & $2^{\text {nd }}(3)$ & $2^{\text {rd }}(3)$ & $3^{\text {rd }}(2)$ \\
\hline Knowledge and skill gap & $4^{\text {th }}(1)$ & $4^{\text {th }}(1)$ & $4^{\text {th }}(1)$ \\
\hline Post harvest problem & & & \\
\hline Harvesting technique & $1^{\text {st }}(3)$ & $1^{\text {st }}(3)$ & $1^{\text {st }}(3)$ \\
\hline Transportation & $2^{\text {nd }}(2)$ & $2^{\text {nd }}(2)$ & $2^{\text {nd }}(2)$ \\
\hline Storage & $3^{\text {rd }}(1)$ & $3^{\text {rd }}(1)$ & $3^{\text {rd }}(1)$ \\
\hline Processing (quality) & $4^{\text {th }}(0)$ & $4^{\text {th }}(0)$ & $4^{\text {th }}(0)$ \\
\hline Marketing constraint & & & \\
\hline Market access & $1^{\text {st }}(4)$ & $1^{\text {st }}(4)$ & $1^{\text {st }}(4)$ \\
\hline High price of inputs & $2^{\text {nd }}(3)$ & $3^{\text {rd }}(2)$ & $3^{\text {rd }}(2)$ \\
\hline Credit access & $4^{\text {th }}(1)$ & $5^{\text {th }}(0)$ & $5^{\text {th }}(0)$ \\
\hline Lack of market information & $3^{\text {rd }}(2)$ & $2^{\text {nd }}(3)$ & $2^{\text {nd }}(3)$ \\
\hline Lack of organized marketing & $4^{\text {th }}(1)$ & $4^{\text {th }}(1)$ & $4^{\text {th }}(1)$ \\
\hline Figures in the parenthesis: score values; Numbers outside the parentheses: ranking &
\end{tabular}

\section{Conclusion and Recommendations}

Crop production is an integral part of the farming system, which plays a crucial role in the livelihood for farm households of the study area. However, limited access to improved seed, diseases and insect pests, drought, declining of soil fertility due to land degradation, increment of farm input costs, high postharvest losses, low institutional support and poor marketing system are the major constraints to crop production in the area. Based on the findings of the study, the following recommendations are given:

- Introduce and promote improved crop varieties is a research priority area focusing toward generating of high yielding, early maturing, and pests resistant varieties in the area.

- Strength research-farmer-extension linkages to develop improved crop varieties adapted to local conditions, and improved management practices

- Improve the technical knowledge and skill of farmers and development agents in crop production and crop protection practices by providing training to increase crop yield.

- Expand irrigation facilities and improve irrigation water use efficiency by improving the irrigation system in the area,

- Participatory promotion of improved farm machineries and storage technologies should be conducted for major cereal crops to reduce grain loss and quality.

- Develop improved postharvest handling and storage technologies to prolons shelf life and minimize postharvest losses for horticultural crops.

- Build the capacity of farmer's cooperatives/unions so as to provide cooperatives for input and output marketing, and creating linkages with value chain actors could be improve the benefit of the farmers. 


\section{References}

[1] Central Statistical Egency CSA, 2015. Agricultural sample surveys. Addis Ababa.

[2] Food and Agriculture Organization FAO, 2014. The united nations office of the fao representative to Ethiopia. Addis Ababa.

[3] Food and Agriculture Organization FAO, 2015. "Ethiopian country programming framework,revised document september 2014."

[4] Mohammed, K. and Afework, B., 2016. "Horticultural crop production and level of consumption in dire dawa administration, Eastern Ethiopia." MAYFEB Journal of Agricultural Science, vol. 1, Available: https://www.researchgate.net/publication/308414621_Horticultural_Crop_Production_and_Level_of_Cons umption_in_Dire_Dawa_Administration_Eastern_Ethiopia

[5] Abdu, M., 2010. Economic impact of prosopis juliflora invasion on agropastoral households and their coping mechanisim: The case of dire dawa administration. Unpublished MSc. Thesis, Haramay University.

[6] Mohammed, K., 2013. "Pest rodent species composition, level of damage and mechanism of control in Eastern Ethiopia." International Journal of Innovation and Applied Studies, vol. 4, pp. 502-511. 